\title{
PENGARUH PENDAPATAN BAGI HASIL MUDHARABAH, MUSYARAKAH DAN MURABAHAH TERHADAP BAGI HASIL TABUNGAN (STUDI PADA KSU BMT TAMAN SURGA JAKARTA)
}

\section{Zaenudin}

\author{
STIE Muhammadiyah Jakarta
}

\begin{abstract}
The effect of Mudharabah, Musyarakah, and Murabahah Revenue Sharing to Saving Share: a Study on KSU BMT Taman Surga Jakarta. This study aims to see whether the effect mudharabah and musyarakah income share, and also murabahah margin income at mudhabahah saving deposit product at BMT Taman Surga Jakarta. The method analysis that used in this study is linier regression, with each variabel tested both concurrently (simultaneously) or separately (partial). The result from this study is there is an positive and significat effect of mudharabah revenue sharing, musyarakah revenue sharing, and murabahah margin whether simultaneously and partial to mudharabah saving deposit share. BMT is expected to increase revenue for the results to further attract customers.
\end{abstract}

Keywords: mudharabah, musyarakah, murabahah, profit sharing, regression

\begin{abstract}
Abstrak. Pengaruh Pendapatan Bagi Hasil Mudharabah, Musyarakah, dan Murabahah Terhadap Bagi Hasil Tabungan: Studi Pada KSU BMT Taman Surga Jakarta. Penelitian ini bertujuan untuk melihat apakah variabel-variabel yang mempengaruhi bagi hasil tersebut yaitu pendapatan bagi hasil mudharabah dan musyarakah dan juga pendapatan margin murabahah benar mempengaruhi bagi hasil tabungan mudharabah yang dilakukan dengan studi kasus pada BMT Taman Surga Jakarta. Penelitian ini melakukan pengujian terhadap variabelvariabel tersebut, yaitu dengan metode uji regresi, dimana setiap variabel diuji baik secara bersamaan (simultan) maupun terpisah (parsial) agar terlihat pengaruh dari masing-masing setiap variabel. Dari hasil pengujian disimpulkan bahwa setiap variabel yang ada yaitu pendapatan bagi hasil mudharabah, musyarakah dan juga margin murabahah secara simultan dan parsial berpengaruh positif terhadap bagi hasil tabungan mudharabah. BMT diharapkan dapat meningkatkan pendapatan bagi hasilnya untuk lebih menarik nasabah.

Kata Kunci: mudharabah, musyarakah, murabahah, bagi hasil, regresi
\end{abstract}




\section{PENDAHULUAN}

Dunia perbankan Indonesia telah kehadiran perbankan syariah yang sudah cukup lama ada. Namun beberapa tahun terakhir ini perkembangan perbankan syariah cukup pesat. Terbukti dengan banyaknya bank konvensional saat ini yang membuka unit usahanya dalam bentuk syariah seperti bank syariah Mandiri, Bank BTN Syariah dan banyak munculnya lembaga keuangan non bank (LKNB) syariah seperti koperasi syariah,BMT, Asuransi Tafakkul, lembaga-lembaga zakat seperti LAZIS, BAZIS, dan Dompet Dhuafa.

Dengan munculnya lembaga-lembaga keuangan non perbankan syariah tersebut menandakan bahwa kesadaran masyarakat Indonesia akan kehalalan transaksi perbankan menjadi sangat penting. Tidak hanya dalam hal meminjam dana namun juga dalam menyimpan dana, dalam perbankan konvensional terdapat bunga yang merupakan keuntungan untuk pihak bank jika nasabah meminjam dana, dan juga diberikan kepada nasabah yang menyimpan dananya pada bank sebagai bentuk balas jasa karena sudah menitipkan dananya. Besaran persentase atas bunga yang di dapat sudah ditentukan oleh pihak bank.

Adapun bank-bank dan lembaga keuangan syariah lainnya memerlukan produk-produk syariah dalam menjalankan operasionalnya yang tentunya sesuai dengan syariat yang bebas akan riba. Berbeda dengan perbankan konvensional dalam perbankan syariah tidak ada bunga, melainkan bagi hasil atau dikenal juga sebagai profit sharing yang artinya pembagian laba.

Sistem bagi hasil menjadi karakteristik tersendiri yang memiliki keunggulan dibanding bunga. Keunggulan ini tidak saja karena telah sesuai dengan akidah Islam, tetapi secara ekonomi juga memliki keunggulan. Dalam mekanisme keuangan syariah model bagi hasil berhubungan dengan usaha pengumpulan dana (funding) maupun penyaluran dana/pembiayaan (financing) (Ridwan, 2011).

Dana yang telah dikumpulkan oleh lembaga keuangan syariah nonbank dari titipan dana pihak ketiga atau titipan lainnya perlu dikelola 
dengan penuh amanah dan istiqomah. Dana tersebut diharapkan dapat mendatangkan keuntungan besar baik untuk nasabah maupun pengelola dana. Prinsip utama yang harus dikembangkan lembaga keuangan Islam dalam kaitan dengan manajemen dana adalah lembaga keuangan Islam harus mampu memberikan bagi hasil kepada penyimpan dana minimal sama dengan atau lebih besar dari suku bunga yang berlaku di bank konvensional, dan mampu menarik bagi hasil dari debitur lebih rendah dari bunga yang diberlakukan di bank konvensional (Muhammad, 2002).

Berdasarkan Fatwa Dewan Syariah Nasional (DSN) Nomor : 15/DSNMUI/IX/2000 tentang prinsip distribusi hasil usaha dalam lembaga keuangan syariah bahwa pembagian hasil usaha diantara pihak (mitra) dalam suatu bentuk usaha kerja boleh didasarkan prinsip. Pertama, bagi Untung (profit sharing), yakni bagi hasil yang dihitung dari pendapatan setelah dikurangi biaya pengelolaan dana, dan boleh pula didasarkan pada prinsip. Kedua, Bagi Hasil (revenue sharing), yakni bagi hasil yang dihitung dari total pendapatan pengelolaan dana dan masing-masing memiliki kelebihan dan kekurangan.

Lembaga keuangan non-bank syariah dengan sistem bagi hasil dirancang untuk terbinanya kebersamaan dalam menanggung risiko usaha dan berbagi hasil usaha antara pemilik dana (shahibul maal) yang menyimpan uangnya di lembaga, dan lembaga selaku pengelola dana (mudharib), dan masyarakat yang membutuhkan dana yang bisa berstatus peminjam dana atau pengelola usaha (Suwiknyo, 2010).

Pada sisi pengerahan dana masyarakat, shahibul maal berhak atas bagi hasil dari usaha lembaga keuangan sesuai dengan porsi yang telah disepakati bersama. Bagi hasil yang diterima oleh shahibul maal akan naik turun secara wajar sesuai dengan keberhasilan usaha lembaga keuangan dalam mengelola dana yang dipercayakan kepadanya.

Dalam sistem keuangan syariah dan Baitul Maal wat Tamwil (BMT), model bagi hasil hanya berlaku untuk akad penyertaan usaha atau kerja sama usaha. Akad ini dapat diterapkan dalam 4 (empat) produk yakni, mudharabah, 
musyarakah, muzara'ah, dan musaqoh. Namun dalam praktiknya yang sering diterapkan baru pada mudharabah dan musyarakah baik untuk funding maupun financing (Ridwan, 2011).

Secara teknis mudharabah adalah akad kerja sama usaha antara dua pihak dimana pihak pertama (shahibul maal) menyediakan seluruh modal, sedangkan pihak lainnya menjadi pengelola (Al Arif, 2012). Bentuk ini menegaskan kerja sama dalam paduan kontribusi 100\% modal kas dari shahibul maal dan keahlian dari mudharib dengan nisbah bagi hasil menurut kesepakatan dimuka. Dalam mudharabah, mudharib sebagai orang yang diberi amanah, ia dituntut untuk bertindak hati-hati dan bertanggung jawab terhadap kerugian yang terjadi karena kelalaiannya. Mudharib diharapkan mempergunakan dan mengelola modal sedemikian rupa untuk menghasilkan laba optimal bagi usaha yang dijalankan tanpa melanggar nilai-nilai syariah islam.

Perjanjian mudharabah dapat juga dilakukan antara beberapa penyedia dana dan pelaku usaha. Jika usaha mengalami kerugian, maka seluruh kerugian ditanggung oleh pemilik dana, kecuali jika ditemukan adanya kelalaian atau kesalahan oleh pengelola dana, seperti penyelewengan, kecurangan, dan penyalahgunaan dana. Keuntungan usaha secara mudharabah dibagi menurut kesepakatan yang dituangkan dalam kontrak, sedangkan apabila rugi ditanggung oleh pemilik modal selama kerugian itu bukan akibat kelalaian si pengelola (Adrian Sutedi, 2009).

Musyarakah secara bahasa berarti mencampur. Dalam hal ini mencampur satu modal dengan modal yang lain sehingga tidak dapat dipisahkan satu sama lain. Musyarakah disebut juga dengan syirkah (Adrian Sutedi, 2009). Musyarakah adalah akad kerja sama antara dua pihak atau lebih untuk suatu usaha tertentu dimana masing-masing pihak memberikan kontribusi dana dengan kesepakatan bahwa keuntungan dan risiko akan ditanggung bersama sesuai dengan kesepakatan. (Al Arif, 2012). 
Musyarakah memiliki karakteristik, yaitu sebagai berikut: Pertama, kerjasama diantara pemilik dana yang mencampurkan dana mereka untuk tujuan mencari keuntungan. Kedua, untuk membiayai suatu proyek tertentu, dimana mitra dapat mengembalikan dana tersebut berikut bagi hasil yang disepakati baik secara bertahap maupun sekaligus. Ketiga, dapat diberikan dalam bentuk kas atau setara kas dan aset non kas termasuk aset tidak berwujud, seperti lisensi, hak paten dan sebagainya.Keempat, setiap mitra tidak dapat menjamin modal mitra lainnya namun mitra yang satu dapat meminta mitra lainnya untuk menyediakan jaminan atas kelalaian atau kesalahan yang disengaja. Kelima, keuntungan musyarakah dapat dibagi diantara mitra searah proporsional sesuai modal yang disetor atau sesuai nisbah yang disepakati. Keenam, kerugian dibebankan secara proporsional sesuai dengan modal yang disetor.

Transaksi musyarakah dilandasi adanya keinginan para pihak yang bekerja sama untuk meningkatkan nilai aset yang mereka miliki secara bersama-sama. Semua bentuk usaha yang melibatkan dua pihak atau lebih dimana mereka secara bersama-sama memadukan seluruh bentuk sumber dana baik yang berwujud maupun tidak berwujud. Komposisi modalnya tidak harus sama. Namun biasanya porsi modal dapat menjadi acuan dalam menentukan porsi nisbah bagi hasilnya.

Murabahah adalah jual beli barang pada harga asal dengan tambahan keuntungan yang disepakati. Penjual harus memberitahu harga produk yang ia beli dan menetukan suatu tingkat keuntungan sebagai tambahannya (Al Arif, 2012). Sebagai contoh, Baitul Maal Wat Tamwil (BMT) bertindak sebagai penjual, sementara sebagai pembeli. Harga jual adalah harga beli penjual dari pemasok ditambah keuntungan (margin). Kedua belah pihak harus menyepakati harga jual dan jangka waktu pembayaran. Harga jual dicantumkan dalam akad jual beli dan jika telah disepakati tidak dapat berubah selama berlakunya akad.

Murabahah selalu dilakukan dengan cara pembayaran cicilan. Margin adalah besarnya keuntungan yang disepakati antara BMT dan nasabah atas transaksi pembiayaan dengan akad jual beli (Ridwan, 2011). 
Margin bersifat tetap tidak berubah sepanjang jangka waktu pembiayaan

Margin adalah besarnya keuntungan yang disepakati antara BMT dan nasabah atas transaksi pembiayaan dengan akad jual beli (Muhammad Ridwan, 2011). Margin bersifat tetap tidak berubah sepanjang jangka waktu pembiayaan. Margin dapat dipengaruhi oleh beberapa faktor, yaitu: pertama, Jumlah pembiayaan. Kedua, Jangka waktu pembiayaan. Ketiga, Sistem pengembalian. Keempat, jumlah biaya yang muncul akibat pembiayaan tersebut. Kelima, tingkat persaingan harga dipasar, baik dengan lembaga keuangan sejenis maupun konvensional. Keenam, karena sifatnya jual beli, maka standar keuntungannya tidak terbatas.

Sesuai dengan sifat bisnis, transaksi murabhah memiliki manfaat salah satunya adalah adanya keuntungan yang muncul dari selisih harga beli dari penjual dengan harga jual kepada nasabah. Selain itu sistem murabahah juga sangat sederhana. Hal tersebut memudahkan penanganan administrasinya di bank syariah. Diantara kemungkinan risiko yang harus diantisipasi antara lain sebagai berikut: Pertama, default atau kelalaian, nasabah sengaja tidak membayar angsuran. Kedua, fluktuasi harga komparatif, ini terjadi bila harga suatu barang dipasar naik setelah bank membelikannya untuk nasabah. BMT tidak bisa mengubah harga jual beli barang tersebut. Ketiga, penolakan nasabah, barang yang dikirim bisa saja ditolak oleh nasabah karena berbagai sebab. Bisa jadi karena rusak dalam perjalanan sehingga nasabah tidak mau menerimanya. Karena itu sebaiknya dilindungi dengan asuransi. Kemungkinan lain karena nasabah merasa spesifikasi barang tersebut berbeda dengan yang ia pesan. Keempat, Dijual, karena murabahah bersifat jual beli dengan utang, maka ketika kontrak ditandatangani, barang menjadi milik nasabah. Nasabah bebas melakukan apa pun terhadap barang tersebut, termasuk untuk menjualnya. Jika terjadi demikian, risiko untuk default akan besar.

Seringkali mudharabah, musyarakah dan murabahah menjadi produk yang menghasilkan pendapatan terbesar baik pada bank-bank syariah, koperasi 
syariah maupun lembaga keuangan syariah lainnya. Ini dapat dibuktikan pada laporan keuangan bank syariah Mandiri tahun 2013 yang dipublikasikan dimana dari total pendapatannya sebesar Rp 5.437 (dalam milyar rupiah), berasal dari pendapatan margin murabahah sebesar Rp 3.773 (dalam milyar rupiah), pendapatan bagi hasil mudharabah sebesar Rp 543 (dalam milyar rupiah), pendapatan bagi hasil musyarakah sebesar Rp 704 (dalam milyar rupiah) yang artinya $92 \%$ pendapatan bank syariah Mandiri didapat dari akad murabahah, mudharabah, dan musyarakah. Begitu pula yang terjadi pada bank BTN Syariah, terlihat pada laporan keuangannya pada tahun 2013 yang dipublikasikan total pendapatannya sebesar Rp 874.875 (dalam jutaan rupiah) yang berasal dari pendapatan margin murabahah sebesar Rp 454.590 (dalam jutaan rupiah), pendapatan bagi hasil mudharabah sebesar Rp 187.510 (dalam jutaan rupiah), pendapatan bagi hasil musyarakah sebesar Rp 116.070 (dalam jutaan rupiah) yang artinya 86,7\% pendapatan bank BTN syariah berasal dari akad murabahah, mudharabah dan musyarakah. Besaran pendapatan yang didapat oleh suatu lembaga keuangan syariah sangatlah penting untuk perputaran kegiatan operasionalnya termasuk dalam menentukan bagi hasil dari suatu produk pembiayaan dan tabungan. Oleh karena itu penulis tertarik untuk mengangkat topik tersebut. Dimana pendapatan bagi hasil dari pembiayaan mudharabah dan musyarakah serta pendapatan margin murabahah yang menjadi variabel yang menentukan besaran bagi hasil tabungan.

Muzayyan Nugroho (2011) dalam penelitiannya yang berjudul "Pengaruh Pendapatan Bagi Hasil, Pendapatan Margin Murabahah dan Dana Simpanan Wadiah Terhadap Bonus Wadiah", menganalisis seberapa pengaruhnya pendapatan bagi hasil dan margin serta dana tabungan wadiah yang didapat oleh sebuah lembaga keuangan syariah dalam menentukan besar kecilnya bonus tabungan sebagai balas jasa imbalan. Hasil yang didapat menunjukkan secara simultan ketiga variabel independen yaitu pendapatan bagi hasil, pendapatan margin murabahah, dan tabungan wadiah dapat berpengaruh terhadap bonus wadiah diterima. Disimpulkan bahwa tabungan wadiah berpengaruh negatif signifikan terhadap pendapatan bagi hasil. 
Sehingga hal yang menyatakan tabungan wadiah berpengaruh positif signifikan terhadap pendapatan bagi hasil ditolak. Ditunjukkan bahwa tidak berpengaruh positif atau signifikan tabungan wadiah terhadap pendapatan margin murabahah. Dengan meningkatnya tabungan wadiah tidak berpengaruh positif dan signifikan terhadap pendapatan margin murabahah. Sehingga dapat dinyatakan bahwa tabungan wadiah berpengaruh positif terhadap pendapatan margin murabahah ditolak. Disimpulkan bahwa pendapatan bagi hasil berpengaruh negatif signifikan terhadap bonus wadia. Sehingga dapat dinyatakan pendapatan bagi hasil berpengaruh positif signifikan terhadap bonus wadiah ditolak. Ditunjukkan bahwa adapengaruh positif signifikan pendapatan margin murabahah terhadap bonus wadiah. Dengan meningkatnya pendapatan margin murabahah diikuti dengan meningkatnya porsi bonus wadiah. Untuk itu dapat dinyatakan bahwa pendapatan margin murabahah berpengaruh positif terhadap bonus wadiah dapat diterima. Dapat ditunjukkan bahwa ada pengaruh positif dan signifikan tabungan wadiah diikuti dengan meningkatnya pendapatan bagi hasil dan pendapatan margin murabahah yang meningkatkan porsi bonus wadiah. Untuk itu dapat dinyatakan bahwa tabungan wadiah berpengaruh positif terhadap bonus wadiah diterima.

Muhammad Ziqri (2012) dalam penelitiannya yang berjudul "Analisis Pengaruh Pendapatan Murabahah, Mudharabah dan Musyarakah Terhadap Profitabilitas Bank" menganalisis pendapatan margin murabahah dan pendapatan bagi hasil dari akad mudharabah dan musyarakah apakah memiliki pengaruh yang signifikan terhadap profitabilitas atau laba usaha yang didapat oleh bank dalam kegiatan operasionalnya. Dalam penelitiannya ditemukan kesimpulan: Dari hasil analisis variabel murabahah, mudharabah, musyarakah terhadap ROE diperoleh hasil bahwa hanya varianel mudharabah yang memiliki pengaruh signifikan terhadap ROE. Sedangkan variabel murabahah dan musyarakah tidak terdapat pengaruh signifikan terhadap ROE. Variabel mudharabah berpengaruh signifikan terhadap ROE, berarti diperoleh bahwa pendapatan yang dihasilkan mudharabah memang mempengaruhi tingkat profitabilitas (ROE) bank. Tingkat pembiayaan mudharabah yang disalurkan 
bank menghasilkan pendapatan yang akan mempengaruhi tingkat profitabilitas (ROE) bank.

Berdasarkan pandangan umum yang telah disusun diatas penulis menarik permasalahan yang berkaitan dengan bagi hasil tabungan mudharabah, yang merupakan imbalan atau balas jasa untuk si pemilik dana karena sudah menyimpan dananya. Mengingat dana yang disimpan nasabah kepada BMT tersebut dialokasikan/disalurkan kembali dalam bentuk produk pembiayaan kepada yang membutuhkan yang tentunya dengan sistem yang sama yaitu dengan adanya bagi hasil dan margin atas pembiayaan yang disepakati bersama tergantung pada produk pembiayaannya, untuk meningkatkan pendapatan atau mendapatkan keuntungan bagi si BMT dalam kegiatannya yang tentunya juga untuk kelangsungan operasional BMT itu sendiri.

\section{METODE}

Dalam penelitian ini, penulis menggunakan metode data kuantitatif dengan menggunakan analisis statistik melalui pendekatan regresi berganda sederhana, yaitu suatu analisis yang mengukur pengaruh antarvariabel yang melibatkan lebih dari dua variabel independen terhadap variabel dependen (Sarwoko, 2005).

Berikut model persamaan dari pengaruh pendapatan bagi hasil mudharabah dan musyarakah serta pendapatan margin murabahan terhadap bagi hasil tabungan mudharabah :

$$
Y=\alpha+\beta_{1} X_{1}+\beta_{2} X_{2}+\beta_{3} X_{3}+\varepsilon
$$

Dimana:

Y : Bagi hasil tabungan mudharabah

$\alpha \quad$ : Intercept

$\beta_{1-3}: \quad$ Konstanta

x1 : Pendapatan bagi hasil mudharabah

x2 : Pendapatan bagi hasil musyarakah

x3 : Pendapatan margin murabahah

$\varepsilon \quad: \quad$ error/sesatan 
Uji F digunakan untuk menunjukkan apakah semua variabel bebas/independen yang dimasukkan dalam model mempunyai pengaruh secara bersama-sama terhadap variabel terikat/dependen. Uji $\mathrm{t}$ digunakan untuk menunjukkan seberapa jauh pengaruh satu variabel penjelas/independen secara individual dalam menerangkan variasi variabel dependen.

Koefisien determinasi $\left(\mathrm{R}^{2}\right)$ digunakan untuk mengukur seberapa jauh kemampuan model dalam menerangkan variasi variabel dependen. Koefisien determinasi adalah diantara nol dan satu, jika nilai kecil atau mendekati nol maka variasi variabel dependen amat terbatas. Sedangkan jika nilai besar atau mendekati satu maka hamper semua informasi yang dibutuhkan untuk memprediksi variabel dependen. Nilai R-Square dikatakan baik jika hasilnya mencapai 0.5 karena nilai R-square berkisar antara 0 sampai 1. Pada umumnya sampel dengan data deret waktu (time series) memiliki R-Square maupun Adjusted R-Square cukup tinggi (diatas 0.5). Pada umumnya memiliki R-Square maupun Adjusted $R$ Square cukup rendah (dibawah 0.5) (Bhuono, 2005).

Uji normalitas data digunakan untuk menguji apakah dalam sebuah model regresi, variabel independen, variabel dependen, atau keduanya (error term) mempunyai distribusi normal atau tidak. Model yang baik adalah data normal atau mendekati normal. Menurut Singgih Santoso (2000) ada beberapa cara mendeteksi normalitas dengan melihat penyebaran data (titik) pada sumbu diagonal dan grafik.

Autokorelasi adalah hubungan antara residual satu observasi dengan residual observasi lainnya. Autokorelasi lebih mudah timbul pada data yang bersifat runtut waktu, karena berdasarkan sifatnya, data masa sekarang dipengaruhi oleh data pada masa-masa sebelumnya. Meskipun demikian, tetap dimungkinkan autokorelasi dijumpai pada data yang bersifat antar objek (cross section) (Winarno, 2009). Untuk menguji keberadaan autokorelasi dalam penelitian ini digunakan statistic $d$ dari Durbin Watson. 
Uji Multikolinearitas digunakan untuk menguji apakah pada model regresi ditemukan adanya korelasi antara variabel independen. Bila variabel-variabel berkorelasi secara sempurna maka disebut multikolnearitas sempurna. Menurut Nachrowi (2006), yang dimaksud multikolinearitas adalah hubungan linear antar variabel bebas. Variabel bebas yang baik adalah variabel bebas yang mempunyai hubungan dengan variabel terikat, tetapi tidak mempunyai hubungan dengan variabel bebas lainnya.

Heteroskedastisitas merupakan keadaan dimana semua gangguan yang muncul dalam fungsi regresi populasi tidak memilki varians yang sama (Shochrul, 2011). Uji ini bertujuan untuk melihat apakah dalam model regresi terjadi ketidaksamaan variabel dari residual satu pengamatan kepengamatan yang lain. Jika varian dari residual satu pengamatan ke pengamatan yang lain tetap, maka disebut homoskedastisitas. Untuk memprediksi ada tidaknya heteroskedastisitas pada suatu model dapat dilihat dari pola gambar scatterplot model tersebut.

Berdasarkan hubungan antara tujuan penelitian terhadap rumusan masalah penelitian ini, maka dapat disusun suatu hipotesis. Hipotesis merupakan jawaban sementara atas suatu persoalan yang masih perlu dibuktikan kebenarannya dan harus bersifat logis, jelas, dan dapat diuji. Hipotesis yang dapat diajukan adalah sebagai berikut: Pertama, terdapat pengaruh pendapatan bagi hasil mudharabah dan musyarakah serta pendapatan margin murabahah terhadap bagi hasil tabungan mudharabah secara simultan. Kedua, terdapat pengaruh positif pendapatan bagi hasil mudharabah terhadap bagi hasil tabungan mudharabah secara parsial. Ketiga, terdapat pengaruh positif pendapatan bagi hasil musyarakah terhadap bagi hasil tabungan mudharabah secara parsial. Keempat, terdapat pengaruh positif pendapatan margin murabahah terhadap bagi hasil tabungan mudharabah secara parsial.

\section{PEMBAHASAN}

Bagi hasil tabungan mudharabah merupakan variabel dependen dalam penelitian ini. Dimana bagi hasil tabungan mudharabah dikeluarkan 
oleh KSU BMT Taman Surga berasal dari pendapatan yang didapatkannya. Besaran jumlahnya tidak menentu dikarenakan bergantung pada profit distribution atau pendapatan bagi hasil dan margin yang diterima oleh KSU BMT Taman Surga dari nasabah atas pembiayaan yang diberikan kepada nasabah.

Besaran jumlah bagi hasil tabungan tidaklah sama. Dikarenakan pendapatan KSU BMT Taman Surga yang berbeda pula setiap bulannya. Begitu pula besaran rata-rata jumlah bagi hasil yang disalurkan untuk tabungan mudharabah tidak menentu setiap tahunnya. Dimana terlihat pada tahun 2012 terjadi kenaikan jumlah bagi hasil yaitu Rp 299.858.25 dibandingkan pada tahun 2011 dimana BMT Taman Surga baru memulai usahanya yaitu sebesar Rp 186.972,88, dan terjadi penurunan di tahun 2013 yaitu sebesar Rp 202.075,42.

Bagi hasil Mudharabah merupakan variabel independen pertama dalam penelitian ini. Bagi hasil mudharabah diberikan oleh nasabah sesuai kesepakatan oleh pihak KSU BMT Taman Surga atas pembiayaan yang diberikan kepada nasabah. Selain dipengaruhi oleh jumlah pembiayaan yang diberikan oleh KSU BMT Taman Surga, bagi hasil mudharabah juga tergantung pada hasil usaha nasabah dimana jika nasabah mengalami keuntungan maka nasabah wajib membayarkan bagi hasil yang sudah disepakati namun jika nasabah mengalami kerugian maka nasabah tidak diwajibkan untuk membayarkan bagi hasilnya begitupun jika nasabah untuk sementara tidak menjalankan usahanya atau tutup maka nasabah juga tidak membayarkan bagi hasilnya kepada KSU BMT Taman Surga namun tetap wajib membayarkan hutang pokoknya.

Pendapatan rata-rata bagi hasil mudharabah yang didapat oleh KSU BMT Taman Surga pada tahun 2011 sebesar Rp 3.564.975,92. Pada tahun 2012 pendapatan rata-rata bagi hasil mudharabah yang didapat oleh KSU BMT Taman Surga dari nasabah sebesar Rp 3.694.655,17 sedangkan pada tahun 2013 pendapatan rata-rata bagi hasil mudharabah yang diperoleh yaitu sebesar Rp 3.072.168,83. Dilihat dari jumlahnya pada tahun 2012 terjadi peningkatan pendapatan bagi hasil mudharabah dibandingkan pada tahun 
2011 dan pada tahun 2013 kembali mengalami penurunan penerimaan pendapatan.

Pendapatan bagi hasil musyarakah merupakan variabel independen yang kedua. Bagi hasil musyarakah yang didapat oleh KSU BMT Taman Surga biasanya lebih besar dibandingkan pendapatan bagi hasil mudharabah tergantung pada nilai proyek yang akan dibiayai. Namun untuk pembiayaan musyarakah lebih sedikit, tidak seperti mudharabah yang banyak peminatnya dan biasanya nominal pembiayaannya lebih kecil dibanding musyarakah.

Variabel independen ketiga pada penelitian yaitu pendapatan margin murabahah. Dimana margin murabahah merupakan keuntungan yang diharapkan oleh KSU BMT Taman Surga atas pembiayaan murabahah. Biasanya pembiayaan ini termasuk pada pembiayaan konsumtif yaitu dimana KSU BMT Taman Surga memberikan pembiayaan kepada nasabah untuk pembelian barang-barang kebutuhan nasabah seperti perlengkapan rumah tangga, elektronik, dan lain sebagainya. Sama dengan bagi hasil, margin pun disepakati oleh kedua belah pihak yaitu KSU BMT Taman Surga Jakarta dan nasabah. Besaran jumlahnya tergantung pada jumlah pembiayaan yang diberikan, sehingga margin yang diinginkan oleh KSU BMT Taman Surga Jakarta pun bervariasi.

Jumlah pendapatan margin murabahah KSU BMT Taman Surga Jakarta tiap tahunnya mengalami peningkatan. Terlihat pada tahun pertama yaitu tahun 2011 rata-rata pendapatan marginnya sebesar Rp 5.464.050,58. Pada tahun berikutnya tahun 2012 mengalami peningkatan yang cukup baik yaitu pendapatan margin sebesar Rp 15.195706 .58 namun pada tahun 2013 peningkatan pendapatan tidak cukup besar. Pada tahun 2013 pendapatan margin yang didapat sebesar $\mathrm{Rp} 15.502 .961,67$ yang artinya terjadi kenaikan namun tidak terlalu banyak.

Uji $\mathrm{F}$ bertujuan untuk mengetahui apakah variabel independen yang digunakan dalam model regresi mampu menjelaskan variabel dependennya, dalam hal ini variabel independennya yaitu pendapatan bagi hasil mudharabah, pendapatan bagi hasil musyarakah dan pendapatan margin murabahah, 
sedangkan variabel dependennya yaitu bagi hasil tabungan mudharabah. Hasil F test jika $p$-value (pada kolom sig.) lebih kecil dari level of significant yaitu 5\% maka variabel independent secara bersama-sama berpengaruh terhadap variabel dependen.

Dari hasil dapat dilihat bahwa hasil p-value menunjukkan 0.000 yang artinya nilai tersebut lebih kecil dari level of significant yaitu 5\% sehingga dapat disimpulkan variabel independent pada penelitian ini yaitu pendapatan bagi hasil mudharabah, pendapatan bagi hasil musyarakah, dan pendapatan margin murabahah secara bersama-sama berpengarauh terhadap variabel dependen yaitu bagi hasil tabungan mudharabah.

Pada uji $\mathrm{t}$ menunjukkan tingkat signifikan variabel PBMDR atau pendapatan bagi hasil mudharabah sebesar 0.000 dan dengan menggunakan tingkat keyakinan $\alpha=5 \%$ maka ditemukan signifikansi yang kuat antara pendapatan bagi hasil mudharabah dengan bagi hasil tabungan mudharabah. Dengan demikian keputusan yang diambil adalah Ho ditolak karena memang mempunyai hubungan yang positif antara pendapatan bagi hasil mudharabah dengan bagi hasil tabungan mudharabah secara parsial, yang artinya hipotesis kedua yaitu terdapat pengaruh positif pendapatan bagi hasil mudharabah terhadap bagi hasil tabungan mudharabah dinyatakan benar dan dapat disimpulkan pendapatan bagi hasil mudharabah merupakan salah satu faktor yang mempengaruhi besar kecilnya bagi hasil tabungan mudharabah yang akan diberikan oleh KSU BMT Taman Surga Jakarta.

Selanjutnya nilai koefisien pada variabel ini yaitu sebesar 0.025 yang menggambarkan setiap adanya penambahan pendapatan bagi hasil mudharabah sebagai satu satuan maka hasil yang akan dierima oleh nasabah akan naik sebesar 0.025. Maka dapat dikatakan jika pendapatan bagi hasil mudharabah yang diterima oleh KSU BMT Taman Surga Jakarta maka akan kemungkinan untuk bertambah pula jumlah bagi hasil tabungan mudharabah yang akan diberikan kepada nasabah. 
Pada uji $\mathrm{t}$ menunjukkan tingkat signifikan variabel PBMSY atau pendapatan bagi hasil musyarakah sebesar 0.002 dan dengan menggunakan tingkat keyakinan $\alpha=5 \%$ maka ditemukan signifikansi yang kuat antara pendapatan bagi hasil musyarakah dengan bagi hasil tabungan mudharabah. Dengan demikian keputusan yang diambil adalah Ho ditolak karena memang mempunyai hubungan yang positif antara pendapatan bagi hasil musyarakah dengan bagi hasil tabungan mudharabah secara parsial, yang artinya hipotesis ketiga yaitu terdapat pengaruh positif pendapatan bagi hasil musyarakah terhadap bagi hasil tabungan mudharabah dinyatakan benar dan dapat disimpulkan pendapatan bagi hasil musarakah merupakan salah satu faktor yang mempengaruhi besar kecilnya bagi hasil tabungan mudharabah yang akan diberikan oleh KSU BMT Taman Surga Jakarta kepada nasabah.

Selanjutnya nilai koefisien pada variabel ini yaitu sebesar 0.007 yang menggambarkan setiap adanya penambahan pendapatan bagi hasil musyarakah sebagai satu satuan maka bagi hasil tabungan yang dierima akan naik sebesar 0.007. Sama dengan pendapatan bagi hasil mudharabah jika pendapatan bagi hasil musyarakah KSU BMT Taman Surga mengalami peningkatan maka kemuingkinan penyaluran bagi hasil tabungan mudharabah juga akan meningkat jumlahnya.

Pada uji $t$ menunjukkan tingkat signifikan variabel PBMSY atau pendapatan margin murabahah sebesar 0.000 dan dengan menggunakan tingkat keyakinan $\alpha=5 \%$ maka ditemukan signifikansi yang kuat antara pendapatan margin murabahah dengan bagi hasil tabungan mudharabah. Dengan demikian keputusan yang diambil adalah Ho ditolak karena memang mempunyai hubungan yang positif antara pendapatan margin murabahah dengan bagi hasil tabungan mudharabah secara parsial, yang artinya hipotesis keempat yaitu terdapat pengaruh positif pendapatan margin murabahah terhadap bagi hasil tabungan mudharabah dinyatakan benar dan dapat disimpulkan pendapatan margin murabahah merupakan salah satu faktor yang mempengaruhi besar kecilnya bagi hasil tabungan 
mudharabah yang akan diberikan oleh KSU BMT Taman Surga Jakarta kepada nasabah.

Selanjutnya nilai koefisien pada variabel ini yaitu sebesar 0.018 yang menggambarkan setiap adanya penambahan pendapatan bagi hasil musyarakah sebagai satu satuan maka bagi hasil yang akan dierima akan naik sebesar 0.018. Sehingga jika pendapatan margin murabahah KSU BMT Taman Surga Jakarta bertambah maka bagi hasil tabungan mudharabah yang akan dibagikan kepada nasabah juga memungkinkan akan meningkat.

Adapun faktor-faktor yang mempengaruhi bagi hasil, terdiri dari faktor langsung dan tidak langsung. Faktor Langsung, terdiri dari: Investment Rate merupakan presentase aktual dana yang diinvestasikan dari total dana yang terhimpun. Jumlah dana yang tersedia untuk diinvestasikan merupakan jumlah dana dari berbaga i sumber dana yang tersedia untuk diinvestasikan. Dana tersebut dapat dihitung dengan menggunakan metode rata-rata saldo minimum bulanan atau rata-rata total saldo harian.

Investment rate dikalikan dengan jumlah dana yang tersedia untuk diinvestasikan, akan menghasilkan jumlah dana aktual yang digunakan. Nisbah (profit sharing ratio) merupakan proporsi pembagian hasil usaha. Nisbah ditetapkan diawal perjanjian/akad, besarannya berbeda antara BMT yang satu dengan BMT yang lainnya begitu juga antara debitur yang satu dengan yang lainnya. Dapat berbeda pula dari satu produk dengan produk yang lainnya.

Faktor Tidak Langsung, terdiri dari: Pertama, Penentuan pendapatan dan biaya mudharabah. BMT dan nasabah melakukan share dalam pendapatan dan biaya (profit and sharing). Pendapatan yang dibagi hasilkan merupakan pendapatan yang diterima dikurangi biaya-biaya. Jika semua biaya ditanggung bank, hal ini disebut revenue sharing. Kedua, kebijakan akuntansi (prinsip dan metode akuntansi). Bagi hasil secara tidak langsung dipengaruhi oleh berjalannya aktivitas yang diterapkan, terutama sehubungan dengan pengakuan pendapatan dan biaya. 
Dalam Keputusan Menteri Negara Koperasi dan Usaha Kecil dan Menengah Republik Indonesia Nomor 91/Kep/M.UKM/IX/2004 Tentang Petunjuk Pelaksanaan Kegiatan Usaha Koperasi Jasa Keuangan Syariah ditetapkan bahwa Nisbah adalah proporsi pembagian keuntungan (bagi hasil) antara pemilik dana (shahibul maal) dan pengelola dana (mudharib) atas hasil usaha yang dikerjasamakan (Ahmad Ifham Sholihin, 2010:458). Mudharib mendapatkan imbalan atas kerjanya, sedangkan shahibul maal mendapat imbalan atas penyertaan modalnya, nisbah keuntungan inilah yang akan mencegah terjadinya perselisihan antara kedua belah pihak mengenai cara pembagian keuntungan.

Nisbah ini ditetapkan dalam akad atau perjanjian. Sebelum akad ditandatangani, nasabah/anggota dapat menawar sampai pada tahap kesepakatan. Hal ini tentunya berbeda dengan sistem bunga, yakni nasabah selalu pada posisi pasif, karena pada umumnya bunga menjadi kewenangan pihak bank. Nisbah keuntungan harus dinyatakan dalam bentuk prosentase antara kedua belah pihak, bukan dinyatakan dalam nilai nominal (Karim, 2010).

Bagi hasil bukan konsep biaya. Dengan demikian bagi hasil tidak mengenal istilah beban pasti (fixed cost). Karena nilai bagi hasil akan didapat setelah terjadi pembukuan usaha. Bagi lembaga keuangan syariah, tidak akan terjadi negative spread sebagaimana pada lembaga keuangan konvensional. Karena bagi hasil dana akan dibayar setelah para debitor membayar bagi hasil pula. Dan bagi debitur tidak akan menjual barangnya dengan harga yang tinggi, karena bagi hasil tidak mungkin dihitung sebagai bagian dari biaya produksi. Bagi hasil baru akan dibayar setelah terjadi penjualan, itupun kemungkinannya dapat saja tidak memberi bagi hasil karena memang usahanya merugi.

\section{SIMPULAN}

Ketiga variabel indpenden yaitu pendapatan bagi hasil mudharabah, pendapatan bagi hasil musyarakah dan pendapatan margin murabahah dengan kontribusi 56\% secara simultan mempengaruhi variabel dependen yaitu bagi hasil tabungan mudharabah. Hasil dari uji $\mathrm{F}$ diperoleh nilai $p$-value 
$=0.000$ lebih kecil dari $\alpha=5 \%$, sehingga dapat disimpulkan Ho ditolak karena ada pengaruh positif secara simultan antara pendapatan bagi hasil mudharabah, pendapatan bagi hasil musyarakah dan pendapatan margin murabahah. Untuk itu Ha yang menyatakan secara simultan ketiga variabel independen yaitu pendapatan bagi hasil mudharabah, pendapatan bagi hasil musyarakah dan pendapatan margin murabahah berpengaruh terhadap bagi hasil tabungan mudharabah diterima.

Pengaruh Bagi Hasil Mudharabah terhadap Bagi Hasil Tabungan Mudharabah pada hasil uji penelitian didapatkan melalui uji t yaitu dimana variabel ini memiliki nilai $p$-value sebesar 0.000 yang artinya lebih kecil dari $\alpha=5 \%$ maka dapat dikatakan bahwa pendapatan bagi hasil mudharabah berpengaruh positif terhadap bagi hasil tabungan mudharabah maka Ho ditolak. Variabel pendapatan bagi hasil musyarakah berdasarkan hasil pengujian pada bab sebelumnya memperoleh hasil pada ujit yaitu nila p-value 0.002 dimana angka tersebut lebih kecil dari nilai $\alpha=5 \%$ maka dapat dikatakan pendapatan bagi hasil musyarakah berpengaruh positif dan signifikan terhadap bagi hasil tabungan mudharabah sehingga Ho ditolak, maka hipotesis yang menyatakan terdapat pengaruh positif antara pendapatan bagi hasil musyarakah terhadap bagi hasil tabungan mudharabah dinyatakan benar. Sehingga jika pendapatan bagi hasil musyarakah mengalami peningkatan maka akan berpengaruh pada jumlah bagi hasil tabungan mudharabah yang akan disalurkan kepada nasabah yang kemungkinan juga akan mengalami peningkatan

Pendapatan margin murabahah pada hasil uji $\mathrm{t}$ didapatkan angka $p$ value sebesar 0.000 yang tentunya lebih kecil dari $\alpha=5 \%$ sehingga sama dengan pendapatan bagi hasil mudharabah yang juga memiliki pengaruh signifikan kepada bagi hasil tabungan mudharabah. Maka Ho ditolak karena variabel independen ini memiliki pengaruh positif terhadap variabel dependen. Jadi hipotesis yang menyatakan terdapat pengaruh positif antara pendapatan margin murabahah terhadap bagi hasil tabungan mudharabah dinyatakan benar. Oleh karenanya jika pendapatan margin murabahah yang diterima KSU BMT Taman Surga mengalami peningkatan maka kemungkinan bagi hasil 
tabungan mudharabah yang akan diberikan kepada nasabah pun juga akan meningkat.

Untuk penelitian selanjutnya dapat menambahkan variabel independen lainnya yang sekiranya dapat mempengaruhi bagi hasil tabungan mudharabah. Penelitian selanjutnya sebaiknya menambah jumlah sampel agar didapat beberapa faktor yang benar-benar akurat dan signifikan mempengaruhi bagi hasil tabungan mudharabah. KSU BMT Taman Surga diharapkan bisa lebih meningkatkan pendapatannya agar bagi hasil tabungan yang disalurkan dapat lebih meningkat, sehingga masyarakat akan lebih tertarik untuk menabung dikarenakan bagi hasil yang menarik.

\section{PUSTAKA ACUAN}

Al Arif, M.N.R. 2012. Lembaga Keuangan Syariah: Suatu Kajian Teoritis Praktis. Bandung: Pustaka Setia

Karim, A.A. 2010. Bank Islam Analisis Fiqih dan Keuangan, Edisi 4. Jakarta : Raja Grafindo.

Kuncoro, M. 2001. Metode Kuantitatif Teori Dan aplikasi Untuk Bisnis dan Ekonomi. Yogyakarta : AMP YPKN.

Mardalis. 2006. Metode Penelitian Suatu Pendekatan Proposal. Jakarta: Bumi Aksara.

Nugroho, M. 2011. Pengaruh Pendapatan Bagi Hasil, Pendapatan Margin Murabahan dan Dana Simpanan Terhadap Bonus Wadiah. (Skripsi Tidak Dipublikasikan). Yogyakarta: UIN Sunan Kalijaga.

Ridwan, M. 2011. Manajemen BMT. Yogyakarta: UII Press.

Sholihin, A.I. 2010. Pedoman Umum Lembaga Keuangan Syariah. Jakarta: Gramedia Pustaka.

Sholihin, A.I. 2010. Buku Pintar Ekonomi Syariah. Jakarta : Gramedia Pustaka.

Soemitra, A. 2009. Bank Dan Lembaga Keuangan Syariah. Jakarta: Prenada Media.

Sutedi, A. 2009. Perbankan Syariah Tinjauan Dan Beberapa Segi Hukum. Jakarta: Ghalia Indonesia.

Suwiknyo, D. 2010. Jasa-jasa Perbankan Syariah. Yogyakarta: Pustaka Pelajar. 
Ziqri, M. 2012. Analisis Pengaruh Pendapatan Murabahah, Mudharabah, dan Musyarakah Terhadap Profitabilitas Bank. (Skripsi Tidak Dipublikasikan). Yogyakarta: UIN Sunan Kalijaga. 